\title{
The Relationship Between International Students' Health Perceptions and Their Healthy Lifestyle Behaviors
}

\author{
Gulseren Citak Tunc ${ }^{1}\left[\right.$ Devin Citak Bilgin² ${ }^{2} \cdot$ Birgül Cerit $^{3}(\mathbb{D}$
}

Accepted: 3 July 2021 / Published online: 10 July 2021

(c) The Author(s), under exclusive licence to Springer Science+Business Media, LLC, part of Springer Nature 2021

\begin{abstract}
This study was carried out to examine the relationship between international students' health perceptions and their healthy lifestyle behaviors. This descriptive and relational study was conducted with 216 international students studying at a university in Turkey. Study data were collected using the descriptive information form, the Perception of Health Scale (PHS) and the Health-Promoting Lifestyle Profile II (HPLP-II). Data were evaluated using descriptive statistics and Pearson correlation analysis. It was determined that the health perception and healthy lifestyle behaviors of the international students involved in this study were moderately positive. The study found a weak and positive relationship between PHS and the physical activity, nutrition and stress management subdimensions of HPLP, while a moderate positive relationship was identified between PHS and the spiritual growth and interpersonal relations subdimensions of HPLP. No relationship was observed between PHS and the health responsibility subdimension of HPLP. The fact that students have a positive perception of health reflects positively on their healthy lifestyle behaviors. It is important to disseminate education programs aimed at improving the health perception and healthy lifestyle behaviors of international students within the university.
\end{abstract}

Keywords International $\cdot$ Student $\cdot$ Perception $\cdot$ Healthy lifestyle $\cdot$ Health behavior

Gulseren Citak Tunc

gctunc@uludag.edu.tr

Nevin Citak Bilgin

nevincitak@yahoo.com

Birgül Cerit

birgulcerit@yahoo.com.tr

1 Department of Psychiatric Nursing, Faculty of Health Sciences, Bursa Uludağ University, Gorukle Campus, Bursa, Turkey

2 Department of Obstetrics and Gynecology Nursing, Bolu Abant Izzet Baysal University, Bolu, Turkey

3 Department of Fundamentals Nursing, Department Faculty of Health Sciences, Bolu Abant Izzet Baysal University, Bolu, Turkey 


\section{Introduction}

Internationalization in the field of higher education is increasing daily. While universities are trying to gain international identity worldwide and make their student profiles multinational in the globalizing world, students want to receive education as international students because doing so provides prestige in terms of ensuring a qualified education and providing different educational experiences (Enterieva \& Sezgin, 2016). The number of international students in the world, which was approximately 800,000 in the 1970 s, is expected to reach 8 million by 2022 (Council of Higher Education [CHE], 2017).

In recent years, there has been an increase in the number of international students in the higher education system in Turkey. While the number of international students in Turkey was 16,656 in the 2000-2001 academic year (CHE, 2017 p. 3 ), this number has increased tenfold in the last twenty years, reaching a total of 154,446 international students in the 2018-2019 academic year (Council of Higher Education [CHE], 2020). The United Nations Educational, Scientific and Cultural Organization (UNESCO) defines international students as "persons who go beyond national or territorial borders for educational purposes and are enrolled as students outside their country of origin" (UNESCO Institute for Statistics, 2020). International students bring innovation to institutions and contribute to the country economy by increasing the cultural diversity of the host country or province.

University life is a dynamic process in which biological, psychological and social changes that direct the lives of young people are experienced intensely (Al-Qahtani, 2019). The health-related behaviors of young people may vary in this process. In this period, young people can adopt positive behaviors that improve their health, but they may also gain negative behaviors (Al-Qahtani, 2019). Healthy lifestyle behaviors (HLBs) can be defined as the implementation of behaviors that have a positive effect on health in daily life and the ability to control behaviors that have negative effects. Studies show that it is easier to acquire HLBs in youth compared to later periods (Sánchez-Ojeda \& De LunaBertos, 2015). It has been reported that in the youth period, which coincides with the time that one attends university, information is more internalized and can be transformed into a lifestyle (Wang et al., 2013).

It is important to improve the perception of health in young people to have them acquire healthy lifestyle behaviors (Tuğut \& Bekar, 2008). Studies conducted with university students demonstrate that students have a moderate level of health perception (Alkan et al., 2017; Khorshid \& Efteli, 2016) and HLBs (Hacıhasanoğlu et al., 2011; Haddad et al., 2004; Karadeniz et al., 2008). Due to the pandemic, the perception of health has currently become an even more important issue. According to the World Health Organization (2020), the coronavirus outbreak has affected more than 107 million people and killed more than 2.4 million people worldwide.

The educational migration of international students for a better career not only offers opportunities, but also includes some threats. Studies support the hypothesis 
that international mobility affects students' HLBs. A study conducted in the USA concluded that international mobility caused changes in students' health behaviors (Yan \& FitzPatrick, 2016). A study conducted in Australia determined that international students' well-being was more negative than the well-being of national students (Skromanis et al., 2018). Research carried out with international students in Turkey centered on problems experienced by students with regard to education and language and problems in economic, psychosocial and cultural areas (Gökyer, 2017; Kumcağ1z et al., 2016). The health perceptions and health behaviors of individuals may differ from one another because they live in different circumstances in society (Alkan et al., 2017; Deasy et al., 2015). Based on this view, this study aimed to identify international students' health perceptions and healthy lifestyle behaviors and to examine the relationship between these two concepts.

This study aimed to seek answers to the following questions:

*What are international students' PHS levels?

*What are international students' HPLP levels?

*Is there a relationship between international students' PHS and HPLP levels?

\section{Method}

\section{Aim of the Study and Study Design}

This descriptive and relational study was performed to determine the relationship between international students' perceptions of health and their HLBs.

\section{Sample of the Study}

Data from the 2018-2019 were used to determine the population of the study (CHE, 2020). The population of the study was composed of 314 international students attending undergraduate education in a university located in the Western Black Sea Region during the 2018-2019 academic year. Sample selection was not made, which means that the entire target population was approached in the study. At the university, there is a community called the "International Students Community" that was established by foreign students. Through these community members, foreign students who were or were not members of the community were contacted. Students were invited to participate in the research. The study was completed with 216 students who volunteered to participate in the study. The participation rate in the study was $69 \%$.

\section{Data Collection Tools}

The research data were collected between April and June 2019 using a personal information form prepared by the researchers, the Perception of Health Scale (PHS) and the Health Promoting Lifestyle Profile II (HPLP II) scale. 
In order to collect data, the members of the "International Student Community" at the university were contacted. The data were collected with the help of this community from foreign students who are members of this community or not. Questionnaire forms were delivered to international students by the researchers in a sealed envelope, and the forms were received from the students in a sealed envelope.

\section{Personal Information Form}

The form consists of 16 questions used to determine international students' sociodemographic and individual characteristics (age, gender, marital status, country of origin, income, faculty/college/class, smoking, alcohol use, etc.).

\section{Perception of Health Scale (PHS)}

The scale was developed by Diamond et al. (2007), and the Turkish validity and reliability study of the scale was carried out by Kadığlu and Yıldız (2012). The scale consists of 15 items about center of control (e.g., Good health is a matter of good luck), certainly (e.g., I would like to be healthier, but I just can't get myself to do what is necessary), importance of health (e.g., I'm willing to spend extra money on things that are healthy for me) and self-awareness (e.g., It is up to me whether I am healthy or not). The Cronbach's alpha value of the scale is 0.77 (Kadığlu \& Yıldız, 2012). The lowest score that can be obtained from the scale is 15 , and the highest score is 75. High scores indicate that one's perception of health has increased in a positive way. The Cronbach's alpha value of the scale was found to be 0.53 in this study.

\section{Health Promoting Lifestyle Profile II (HPLP II)}

The scale was developed to evaluate health-promoting behaviors in relation to the healthy lifestyle of the individual (Walker et al., 1987). A Turkish validity and reliability study was carried out by Bahar et al. (2008). The 4-point Likert-type scale consists of 52 items and six subdimensions: health responsibility (HR), physical activity (PA), nutrition (D), spiritual growth (SG), interpersonal relations (IR) and stress management (SM). The lowest score that can be obtained from the scale is 52 , and the highest score is 208. High scores on the scale indicate a high level of healthy lifestyle behaviors. In Bahar et al. (2008) study, HPLP II Scale the Cronbach's alpha internal consistency coefficient was calculated as 0.92 and it was found to be 0.90 in this study. 


\section{Analysis of the Research Data}

The Statistical Package for Social Sciences (SPSS) 22.0 package program was used in data analysis. The suitability of the data for normal distribution was examined with skewness and kurtosis values. Skewness and kurtosis values between +2.5 and -2.5 indicate that the data show a normal distribution. The data showed a normal distribution in this study (PHS: skewness 0.674, kurtosis 0.451; HPLP: skewness 0.230 , kurtosis 0.446 ). Accordingly, number, percentage, mean and standard deviation were used as descriptive statistics in the study, and the relationship between the variables was examined by Pearson correlation analysis. According to the literature, the strength of the correlation coefficient was high $(0-0.29$ poor, $0.30-0.64$ moderate, 0.65-0.84 high, 0.85-1 very high) (Ural \& Kılıç, 2013). The relationship between the variables was interpreted based on this definition in the study.

\section{Research Ethics}

This research was carried out in conformity with the principles of the Helsinki Declaration. Ethics committee approval to conduct the research was obtained (protocol number 2019/117). The purpose of the study was explained to the students who participated in the study. Written and verbal consent was obtained, and the participants were told that they could leave the study at any time they wished. To use the scales, permission was obtained from the researchers who conducted the validity and reliability study.

\section{Results}

Table 1 presents the descriptive characteristics of international students participating in this study. A total of $41.7 \%$ of the students were female, $58.3 \%$ were male, their mean age was $22.12 \pm 2.83$ years, and $92.1 \%$ were single. One-third of the students came from African countries (Togo, Mali, Nigeria, etc.) and the majority $(69.5 \%)$ lived within the province. A total of $68.5 \%$ of the students stated that their income was equal to their expenses, $74.1 \%$ of them stayed in a dormitory, and $1 / 4$ of the participant group received training in the field of health. The mean body mass index (BMI) was $23.6 \pm 3.29$, and $1 / 3$ of the students were mildly obese $(32.0 \%)$ based on BMI. Almost all (97.2\%) of them reported having no chronic disease (Table 1).

Figure 1 displays students' lifestyle behaviors. Approximately $1 / 5$ of the students smoked, and 1/10 used alcohol. The rate of students engaged in physical activity was $45.4 \%$. Half of the students were members of the student community, $82.4 \%$ of them stated that they socialized by meeting with friends, and $43.5 \%$ of them socialized via social media (Fig. 1).

Table 2 presents the participant group's PHS and HPLP mean scale scores. The students' mean PHS score was $47.55 \pm 6.49$, and their mean HPLP total score was 
Table 1 Descriptive characteristics of international students $(N=216)$

\begin{tabular}{|c|c|c|}
\hline Characteristic & $n$ & $\%$ \\
\hline \multicolumn{3}{|l|}{ Gender } \\
\hline Female & 90 & 41.7 \\
\hline Male & 126 & 58.3 \\
\hline Age $($ mean $\pm S D)$ & $22.12 \pm 2.83$ & Range (18-30) \\
\hline \multicolumn{3}{|l|}{ Marital status } \\
\hline Unmarried & 199 & 92.1 \\
\hline Married & 17 & 7.9 \\
\hline \multicolumn{3}{|l|}{ Nationality } \\
\hline Europe & 9 & 4.2 \\
\hline Asia & 50 & 23.1 \\
\hline Africa & 157 & 72.7 \\
\hline \multicolumn{3}{|l|}{ Longest lived place } \\
\hline Province & 150 & 69.5 \\
\hline Town & 43 & 19.9 \\
\hline Village & 23 & 10.6 \\
\hline \multicolumn{3}{|l|}{ Grade } \\
\hline $1 \mathrm{st}$ & 95 & 44.0 \\
\hline 2 nd & 61 & 28.2 \\
\hline 3 rd & 40 & 18.5 \\
\hline 4 th & 20 & 9.3 \\
\hline \multicolumn{3}{|l|}{ Profession } \\
\hline *Health and sports sciences & 54 & 25.0 \\
\hline$* *$ Other than health profession & 162 & 75.0 \\
\hline \multicolumn{3}{|l|}{ BMI } \\
\hline Low (under 18.5) & 5 & 3.4 \\
\hline Normal (18.5-24.9) & 90 & 61.2 \\
\hline Slightly obese (25-29.9) & 47 & 32.0 \\
\hline Obese (30 and over) & 5 & 3.4 \\
\hline $\mathrm{BMI}($ mean $\pm \mathrm{SD})$ & $23.68 \pm 3.29$ & Range (16.53-35.11) \\
\hline \multicolumn{3}{|l|}{ Income } \\
\hline Income more than expenses & 31 & 14.4 \\
\hline Equal income and expenses & 148 & 68.5 \\
\hline Income less than expenses & 37 & 17.1 \\
\hline \multicolumn{3}{|l|}{ Place of residence } \\
\hline Dormitory & 160 & 74.1 \\
\hline Student house & 41 & 19.0 \\
\hline Family-relative & 15 & 6.9 \\
\hline \multicolumn{3}{|l|}{ Chronic disease } \\
\hline Yes & 6 & 2.8 \\
\hline No & 210 & 97.2 \\
\hline
\end{tabular}

$B M I$ body mass index, $S D$ standard deviation

*Faculty of Health Sciences, Faculty of Medicine, Faculty of Sports Sciences, Faculty of Dentistry

**Faculty of Arts and Sciences, Faculty of Education, Faculty of Engineering and Architecture, Faculty of Economics and Administrative Sciences 


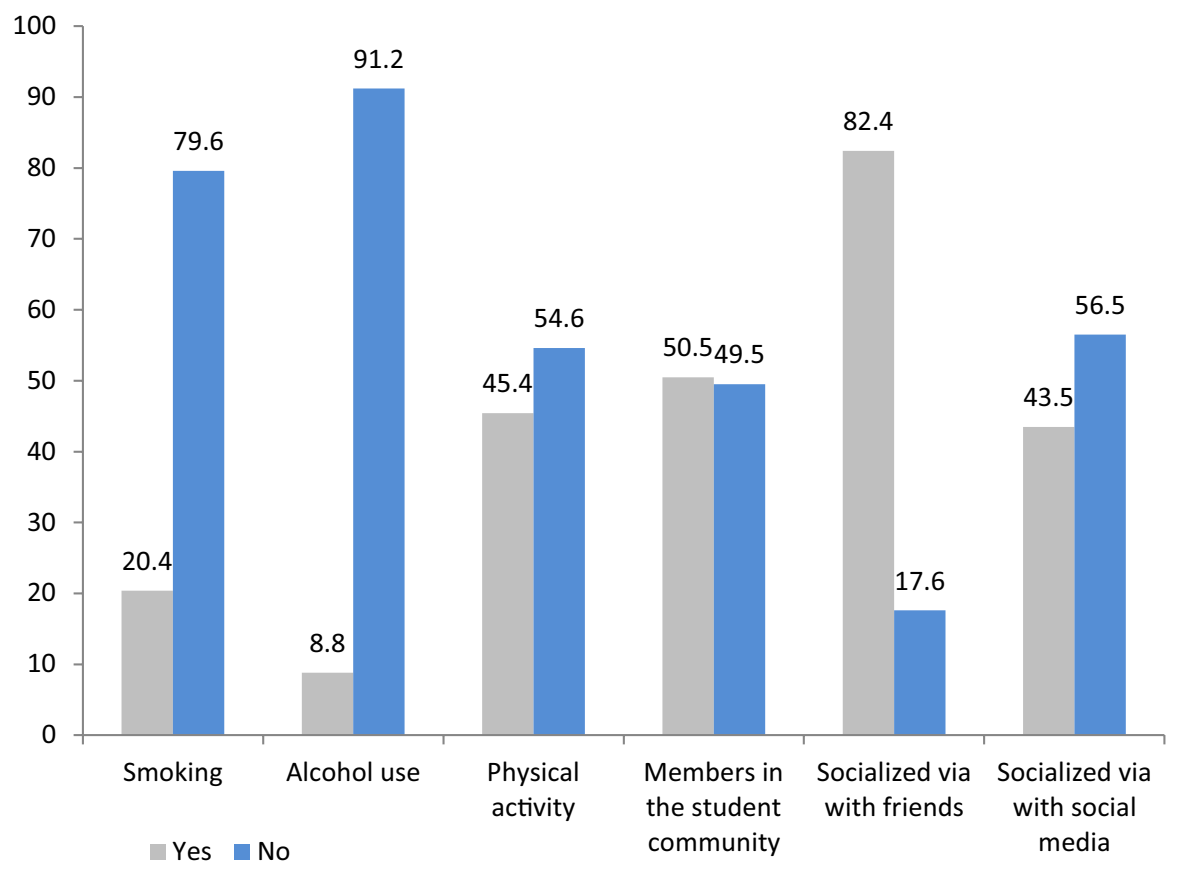

Fig. 1 Lifestyle behaviors of international students

Table 2 Mean scale scores of international students' perception of health and health-promoting lifestyle behaviors $(N=216)$

\begin{tabular}{llll}
\hline Scales & Mean \pm SD & $\begin{array}{l}\text { Recieved score (Min, } \\
\text { Max) }\end{array}$ & $\begin{array}{l}\text { Expected } \\
\text { score (Min, } \\
\text { Max) }\end{array}$ \\
\hline $\begin{array}{l}\text { Perception of health scale } \\
\text { HPLP II and subscales }\end{array}$ & $47.55 \pm 6.49$ & $34-68$ & $15-45$ \\
Health responsibility (HR) & $20.82 \pm 4.06$ & $11-35$ & $9-36$ \\
Physical activity (PA) & $19.06 \pm 3.83$ & $11-32$ & $8-32$ \\
Nutrition (N) & $21.47 \pm 3.78$ & $11-31$ & $9-36$ \\
Spiritual growth (SG) & $23.24 \pm 4.65$ & $12-35$ & $9-36$ \\
Interpersonal relations (IR) & $22.45 \pm 4.32$ & $11-34$ & $9-36$ \\
Stress management (SM) & $19.57 \pm 3.37$ & $10-30$ & $8-32$ \\
\hline
\end{tabular}

HPLP-II health-promoting lifestyle profile II, $H R$ health responsibility, $P A$ physical activity, $N$ nutrition, $S G$ spiritual growth, $I R$ interpersonal relations, $S M$ stress management

126.65 \pm 18.58 . The mean scores for the HPLP subdimension were as follows: HR: $20.82 \pm 4.06$, PA: $19.06 \pm 3.83$, D: $21.47 \pm 3.78$; SG: $23.24 \pm 4.65$ and IR: $22.45 \pm 4.32$; SM: $19.57 \pm 3.37$. 
Table 3 The relationship between international students' perception of health and healthpromoting lifestyle behaviors $(N=216)$

\begin{tabular}{lll}
\hline HPLP-II & \multicolumn{2}{l}{ Perception of health } \\
\cline { 2 - 3 } & $r$ & $p$ \\
\hline Health responsibility (HR) & 0.076 & 0.266 \\
Physical activity (PA) & $0.215^{* *}$ & 0.001 \\
Nutrition (N) & $0.162^{*}$ & 0.017 \\
Spiritual growth (SG) & $0.369^{* *}$ & 0.000 \\
Interpersonal relations (IR) & $0.328^{* *}$ & 0.000 \\
Stress management (SM) & $0.269^{* *}$ & 0.000 \\
Total HPLP scores & $0.311^{* *}$ & 0.000 \\
\hline
\end{tabular}

$H P L P-I I$ health-promoting lifestyle profile II, $H R$ health responsibility, $P A$ physical activity, $N$ nutrition, $S G$ spiritual growth, $I R$ interpersonal relations, $S M$ stress management

$* p<0.05 * * p<0.01$

Table 3 examines the relationship between students' health perceptions and their HPLP. A weak, positive relationship was found between students' health perceptions and the physical activity $(r=0.22, p<0.01)$, nutrition $(r=0.16, p<0.05)$ and stress management $(r=0.26, p<0.001)$ subdimensions of the HPLP. A moderate, positive and significant relationship was found between students' health perception and the spiritual growth $(r=0.37, p<0.001)$ and interpersonal relations $(r=0.33, p<0.001)$ subdimensions of HPLP. However, there was no relationship between health perception and the health responsibility subscale of the HPLP $(p>0.05)$.

\section{Discussion}

International students' perceptions of health were found to be moderate in this study, and this result is similar to conclusions drawn in other studies conducted with university students in Turkey (Özdelikara et al., 2018; Yalnızoğlu-Çaka et al., 2017). However, another study determined that students' perceptions of health were negative (Çilingir \& Aydın, 2017), and a qualitative study conducted with international students found that students evaluated their current health status more negatively than their health status in their home country (Babadağ et al., 2014). A study conducted in Korea found a positive relationship between positive interpersonal relationships and social environment, free time activities, participation in volunteer activities and health perception (Lee et al., 2015). Engagement in a sports-related activity group was found to create a sense of belonging and was found to be effective in reducing social anxiety (Wilcox et al., 2006). In this context, the fact that half of the students in this study were members of a student community, participated in sports activities and interacted with other international students may have positively affected their perception of health. However, the fact that students have a moderate level of positive health perception may suggest that they need support in raising their awareness of health promotion and transforming it into behavior. 
International students' mean HPLP total score was determined to be $126.65 \pm 18.58$ in this study. Examining similar studies in the literature shows that students' mean HLB scores were higher than the value found in this study (Çitak Bilgin et al., 2019; Gore et al., 2021). This result may be related to the effect of international mobility on students' lifestyles. A study conducted with Nigerian students studying at universities in the UK found that students had negative behaviors related to nutrition, stress and physical activity due to insufficient income (Alloh et al., 2018). A qualitative study conducted with graduate students in the USA concluded that the greatest reason for regular physical activity was the desire to lose weight. In the same study, students stated that they gained weight because of fast food-based unhealthy nutrition they got used to when they first came to the country, but then they started to exercise to lose this weight (Shuang \& Zizzi, 2018). A survey conducted with national students in Turkey found that even changing provinces in the same country resulted in difficulties in adaptation, sociocultural problems and health problems (Kumcağız et al., 2016).

HLB increases well-being, individual satisfaction and productivity and prevents risky behaviors such as unhealthy nutrition, lack of physical activity and substance use. A study focusing on the subdimensions of the HLBS determined that international students' lowest mean scores were related to stress management and physical activity. The inability to manage stress may lead students to display risky behaviors (smoking/alcohol) and overeating. Limited physical activity and overeating may cause obesity. The growing obesity epidemic, generally in the West and especially in the USA, results in worsening health, early and preventable disease onset, and excessive healthcare costs (Anshel \& Smith, 2014). Unhealthy nutrition habits and inadequate physical activity are common problems among university students (Almutairi et al., 2018). A study conducted in Ireland with national students identified that students had risky health behaviors such as unhealthy nutrition (26\%), physical inactivity (26\%) and smoking (17\%) (Deasy et al., 2015). The findings regarding the insufficiency of physical activity in this study are similar to the results of national and international research (Almutairi et al., 2018; Gore et al., 2021; Hwang \& Oh, 2020). Studies show that physical activity among students varies depending on many factors (gender, department of study, presence of chronic disease, etc.), as well as perception of health (Çıtak Bilgin et al., 2019; Hwang \& Oh, 2020; Varela-Mato et al., 2012). In this study, 1/3 of the international students had a high BMI. Since the consequences of obesity and a lack of activity in international students can be very important, this factor should never be ignored.

This study concluded that international students' most positive behaviors regarding healthy lifestyle behaviors were observed in the spiritual growth and interpersonal relations subdimensions. This finding is similar to the conclusions of studies conducted with university students in Turkey (Çıtak Bilgin et al., 2019), India (Gore et al., 2021), Saudi Arabia (Al-Qahtani, 2019), Japan (Wei et al., 2012) and Korea (Hwang \& Oh, 2020). This study also demonstrated that language and discourse do not create a barrier in communication. Spiritual growth determines individuals' life goals, to what degree they know themselves and their self-development skills. The finding in many studies that spiritual growth is the highest score for both national and international university students suggests that university students move toward their goals in a planned 
manner by being aware of their strengths and the aspects that can be improved in their lives and that they continue their lives by taking responsibility in this context. It should also be considered that culture and belief systems are important in an international setting. In a study involving university students in Canada, it was determined that spirituality played a positive role in quality of life and health during the COVID-19 pandemic (Cherblanc et al., 2021).

Perception of health is related to individuals' assessment of the effect of their well-being on their physical, mental and social functionality (Anshel \& Smith, 2014). According to the health belief model, perception of health status affects health behaviors and health responsibility. For this reason, the perception of health is closely related to the process of promoting healthy living, which aims to ensure that individuals acquire and maintain healthy lifestyle behaviors (Karaca \& Aslan, 2019; Özdelikara et al., 2018). A study of 13,179 people who responded to the National Health Interview Survey found that people who pray for their health have a lifestyle that includes many behaviors that have the potential to improve their health (Harrigan, 2011). The present study identified that international students' perception of health was positively associated with physical activity, nutrition, stress management, spiritual growth, and interpersonal relations. This finding is consistent with the literature. It has been reported that students' positive evaluation of their health positively affects their understanding of health and social life in future (Çilingir \& Aydın, 2017). Having a positive perception of health is important in maintaining, improving and motivating health (Hwang \& Oh, 2020; Tuğut \& Bekar, 2008). A qualitative study conducted with international students determined that compared to the general student population, international students received less medical support for their diseases and ailments, used more traditional methods of treatment and experienced cultural insensitivity in regard to health care (Collins, 2001). In this context, it can be argued that international students' positive perceptions of health are directly related to the promotion of healthy lifestyles.

University life is a period in which individuals take more responsibility for health-related decisions (Özdelikara et al., 2018). Individuals who care about their health are expected to be sensitive in regards to health responsibility and to be able to demonstrate preventive and health-promoting behaviors that are appropriate for their health. Unlike the literature, this study found no relationship between health perception and health responsibility. It is known that perceived benefits and barriers to preventive and protective health behaviors affect health responsibility. It can be argued that socioeconomic status and psychosocial adaptation problems also affect students' behaviors aimed at protecting and maintaining their health, even for students who care about their health.

\section{Study Limitations}

The study was conducted with international students enrolled in a university and cannot be generalized to all students. However, reaching $69 \%$ of the target population in the study is a good outcome. Acculturation also has an impact on health 
behavior, but it is not clear how the health behaviors of students are affected by the host culture. In this study, the Cronbach's alpha value of the PHS was 0.53, and this value is one of the study limitations.

\section{Suggestions}

Taking the necessary measures, providing guidance services and collecting information about international students are among the obligations of the institutions where international students study so that international students can continue their education successfully (Ministry of National Education, 1983). It is imperative to evaluate international students' perceptions of health first while attempting to determine their healthy lifestyle behaviors. For this reason, studies should be carried out to identify the perception of health and health responsibility for students who are continuing their education and training at universities and those who aim to start their education and training at universities. In the literature, it is stated that international students face acculturation stress due to sociocultural differences (Schartner, 2015). Therefore, education programs related to stress management should be planned, and international students should be included in these programs. In addition, the relationship between health perception and healthy lifestyle behaviors should also be examined through qualitative studies. Morover, studies can be planned to compare the health perceptions and healthy lifestyle behaviors of Turkish and international students.

\section{Conclusion}

Determining the health perceptions and health behaviors of international students is crucial in terms of making decisions about health services that will be offered and in terms of establishing relevant policies in internationalization activities for the future. This research concluded that the health perceptions of international students in Turkey were at a moderate level. It was identified that a positive perception of health reflects positively on healthy lifestyle behaviors.

Acknowledgements We would like to thank Awal Mubarak Mohammed for his support in collecting data.

Author contributions GCT, NCB and BC designed the study; NCB and BC collected the data; GCT and NCB analyzed the data; GCT, NCB and BC drafted the manuscript. All authors approved the final version of the study for submission.

Funding This research did not receive any specific grant from funding agencies in the public, commercial, or not-for-profit sectors.

\section{Declarations}

Conflict of interest The authors declare that they have no financial or non-financial conflict of interest with any organization related with the contents of this paper. 
Ethical Approval This article does not contain any studies with human participants or animals performed by any of the authors. All procedures performed in this study including data collection from the participants were in accordance with the 1964 Declaration of Helsinki and its later amendments or comparable ethical standards.

Informed Consent All the research participants were informed about the objectives and procedures of the study. Informed consent was obtained from all individual participants included in the study.

\section{References}

Alkan, S. A., Özdelikara, A., \& Boğa, N. M. (2017). Hemşirelik öğrencilerinin sağlık algılarının belirlenmesi [Determination of nursing students' health perception]. GÜSBD [Gümüshane University Journal of Health Sciences], 6(2), 11-21.

Alloh, F. T., Tait, D., \& Taylor, C. (2018). Away from home: A qualitative exploration of health experiences of Nigerian students in a U.K. University Journal of International Students, 8(1), 1-20. https://doi.org/10.32674/jis.v8i1.149

Almutairi, K. M., Alonazi, W. B., Vinluan, J. M., Almigbal, T. H., Batais, M. A., Alodhayani, A. A., \& Alhoqail, R. I. (2018). Health promoting lifestyle of university students in Saudi Arabia: A crosssectional assessment. BMC Public Health, 18(1), 1-10. https://doi.org/10.1186/s12889-018-5999-z

Anshel, M. H., \& Smith, M. (2014). The role of religious leaders in promoting healthy habits in religious institutions. Journal of Religion and Health, 53, 1046-1059. https://doi.org/10.1007/ s10943-013-9702-5

Al-Qahtani, M. F. (2019). Comparison of health-promoting lifestyle behaviours between female students majoring in healthcare and non-healthcare fields in KSA. Journal of Taibah University Medical Sciences, 14(6), 508-514. https://doi.org/10.1016/j.jtumed.2019.10.004

Babadağ, B., Çulha, G., \& Köşgeroğlu, N. (2014). Bir sağlık yüksekokulunda öğrenim gören yabancı uyruklu öğrencilerin sağlık alanında karşılaştığı sorunların belirlenmesi [Determining the health problems of foreign students studying in a health school]. Gümüşhane Üniversitesi Sağllk Bilimleri Dergisi [Gümüşhane University Journal of Health Sciences], 3(1), 622-631.

Bahar, Z., Beşer, A., Gördes, N., Ersin, F., \& Kıssal, A. (2008). Sağlıklı yaşam biçimi davranışları ölçeği II'nin geçerlik ve güvenirlik çalışması [Validity and reliability study of the healthy lifestyle behaviors scale II]. C.U. Hemşirelik Yüksekokulu Dergisi [Cumhuriyet University Journal of Nursing School], 12, 1-13.

Cherblanc, J., Bergeron-Leclerc, C., Maltais, D., Cadell, S., Gauthier, G., Labra, O., \& Ouellet-Plamondon, C. (2021). Predictive factors of spiritual quality of life during the COVID-19 pandemic: A multivariate analysis. Journal of Religion and Health, 60, 1475-1493. https://doi.org/10.1007/ s10943-021-01233-6

Collins, K. F. (2001). International students' perceptions of health care. The Journal of School Nursing, 17(3), 140-147. https://doi.org/10.1177/10598405010170030501

Çıtak, B. N., Ak, B., Cerit, B., Ertem, M., \& Çıtak, T. G. (2019). Üniversite öğrencilerinin sağlıklı yaşam biçimi davranışlarının belirlenmesi. [Determination of healthy lifestyle behavior of university students]. Să̆lık Akademisi Kastamonu [Health Academy Kastamonu], 4(3), 188-210. https://doi.org/ $10.25279 /$ sak.525847

Çilingir, D., \& Aydın, A. (2017). Hemşirelik bölümünde öğrenim gören öğrencilerin sağlık algısı [Department of nursing students' perception of health]. FNJN [Florence Nightingale Nursing Journal], 25(3), 167-176. https://doi.org/10.17672/fnjn.343254

Council of Higher Education. (2017). Yükseköğretimde uluslararasılaşma strateji belgesi 2018-2022. [Internationalization strategy document in higher education 2018-2022]. https://www.yok.gov.tr/ Documents/AnaSayfa/Yuksekogretimde_Uluslararasilasma_Strateji_Belgesi_2018_2022.pdf.

Council of Higher Education. (2020). 2018-2019 student numbers by nationality report. https://istatistik. yok.gov.tr/.

Deasy, C., Coughlan, B., Pironom, J., Jourdan, D., \& Mannixmcnamara, P. (2015). Psychological distress and lifestyle of students: Implications for health promotion. Health Promotion International, 30(1), 77-87. https://doi.org/10.1093/heapro/dau086 
Diamond, J. J., Becker, J. A., Arenson, C. A., Chambers, C. V., \& Rosenthal, M. P. (2007). Development of a scale to measure adults' perceptions of health: Preliminary findings. Journal of Community Psychology, 35(5), 557-561. https://doi.org/10.1002/jcop.20164

Enterieva, M., \& Sezgin, F. (2016). Turki cumhuriyetlerden Türkiye'ye gelen yükseköğretim öğrencilerinin akademik ve sosyal beklentilerinin karşılanma düzeyi. [The fulfilment level of Turkic republics higher education students' academic and social expectations in Turkey]. Yükseköğretim ve Bilim Dergisi [Journal of Higher Education and Science], 6(1), 102-115.

Gore, M. N., Menon, K. C., Safai, A. A., Shukla, S., \& Yeravdekar, R. (2021). Determinants of healthpromoting lifestyles amongst Indian University students. International Journal of Health Promotion and Education, 59(3), 135-144. https://doi.org/10.1080/14635240.2020.1726202

Gökyer, N. (2017). Yabancı uyruklu üniversite öğrencilerinin psikolojik uyumları. [Psychological adaptation of foreign university students]. Yükseköğretim ve Bilim Dergisi [Journal of Higher Education and Science ], 7(1), 98-108.

Hacıhasanoğlu, R., Yıldırım, A., Karakurt, P., \& Sağlam, R. (2011). Healthy lifestyle behaviour in university students and influential factors in eastern Turkey. International Journal of Nursing Practice, 17, 43-51. https://doi.org/10.1111/j.1440-172X.2010.01905.X

Haddad, L., Kane, D., Rajacich, D., Cameron, S., \& Al-Ma Aitah, R. A. (2004). Comparison of health practices of Canadian and Jordanian nursing students. Public Health Nursing, 21(1), 85-90. https:// doi.org/10.1111/j.1525-1446.2004.21112.x

Harrigan, J. T. (2011). Health promoting habits of people who pray for their health. Journal of Religion and Health, 50, 602-607. https://doi.org/10.1007/s10943-009-9293-3

Hwang, Y., \& Oh, J. (2020). Factors affecting health-promoting behaviors among nursing students. International Journal of Environmental Research and Public Health, 17(17), 6291. https://doi.org/10. 3390/ijerph17176291

Kadioglu, H., \& Yildiz, A. (2012). Sağlık algısı ölçeğinin Türkçe çevriminin geçerlilik ve güvenirliği [Validity and reliability of Turkish version of perception of health scale]. Türkiye Klinikleri Tip Bilimleri Dergisi [Turkey Clinics Journal of Medical Sciences], 32(1), 47-53. https://doi.org/10.5336/ medsci.2010-21761

Karaca, T., \& Aslan, S. (2019). Hemşirelik öğrencilerinin sağlık durumu algılarının ve sağlıklı yaşam biçimi davranışlarının belirlenmesi [Determination of health status perceptions and healthy life style behaviors of nursing students]. ACU Sağllk Bilimleri Dergisi [ACU Journal of Health Sciences], 10(4), 734-739. https://doi.org/10.31067/0.2019.223

Karadeniz, G., Uçum, Y. E., Dedeli, Ö., \& Karaağaç, Ö. (2008). Üniversite öğrencilerinin sağlıklı yaşam biçimi davranışları [The healthy life style behaviors of university students]. TAF Preventive Medicine Bulletin, 7(6), 497-502.

Khorshid, L., \& Efteli, E. (2016). İki farklı bölüm öğrencilerinin sağlık algılarının karşılaştırılması. [Comparison of health perception of two different divisions' student]. Ege Üniversitesi Hemşirelik Fakültesi Dergisi [Journal of Ege University Nursing Faculty], 32(2), 1-10.

Kumcağız, H., \& Dadashzade, A. K. (2016). Ondokuz Mayıs Üniversitesi'ndeki yabancı uyruklu öğrencilerin sınıf düzeylerine göre yaşadıkları sorunlar [Problems of foreign students at Ondokuz Mayıs University by grade levels]. Ondokuz Mayıs Üniversitesi Ĕ̆itim Fakültesi Dergisi [Ondokuz. Mayis University Journal of Faculty of Education], 35(2), 37-50.

Lee, J. A., Park, J., \& Kim, M. (2015). Social and physical environments and self-rated health in urban and rural communities in Korea. International Journal of Environmental Research and Public Health, 12(11), 14329-14341. https://doi.org/10.3390/ijerph121114329

Ministry of National Education. (1983). Law on foreign students getting education in Turkey. https:// www.tbmm.gov.tr/tutanaklar/KANUNLAR_KARARLAR/kanuntbmmc066/kanundmc066/kanun dmc06602922.pdf.

Özdelikara, A., AğaçdikenAlkan, S., \& Mumcu, N. (2018). Hemşirelik öğrencilerinde sağlık algısı, sağlık anksiyetesi ve etkileyen faktörlerin belirlenmesi [Determination of health perception, health anxiety and effecting factors among nursing students]. Bakırköy Tip Dergisi [Medical Journal of Bakırköy], 14(3), 275-282.

Sánchez-Ojeda, M. A., \& De Luna-Bertos, E. (2015). Healthy lifestyles of the university population. Nutricion Hospitalaria, 31(5), 1910-1919. https://doi.org/10.3305/nh.2015.31.5.8608

Schartner, A. (2015). 'You cannot talk with all of the strangers in a pub': A longitudinal case study of international postgraduate students' social ties at a British university. Higher Education, 69(2), 225241. https://doi.org/10.1007/s10734-014-9771-8 
Skromanis, S., Cooling, N., Rogers, B., Purton, T., Fan, F., Bridgman, H., Harris, K., Presser, J., \& Mond, J. (2018). Health and well-being of international university students, and comparison with domestic students, in Tasmania, Australia. International Journal of Environmental Research and Public Health, 15(6), 1147. https://doi.org/10.3390/ijerph15061147

Shuang, L., \& Zizzi, S. (2018). A Case study of international students' social adjustment, friendship development, and physical activity. Journal of International Students, 8(1), 389-408. https://doi. org/10.32674/jis.v8i1.171

Tuğut, N., \& Bekar, M. (2008). Üniversite öğrencilerinin sağlığı algılama durumları ile sağlıklı yaşam biçimi davranışları arasındaki ilişki [The relationship between university students' perception of health and healthy lifestyle behaviors]. Atatürk Üniversitesi Hemşirelik Yüksekokulu Dergisi [Journal of Atatürk University School of Nursing], 11(3), 17-26.

UNESCO Institute for Statistics. (2020). International (or internationally mobile) students" clause. http:// uis.unesco.org/en/glossary-term/international-or-internationally-mobile-students.

Ural, A., \& Kılıç, İ. (2013). Bilimsel araştırma süreci ve SPSS ile veri analizi [Scientific research process and data analysis with SPSS]. (4th ed.). Detay Press.

Walker, S. N., Sechrist, K. R., \& Pender, N. J. (1987). The health-promoting lifestyle profile: Development and psychometric characteristics. Nursing Research, 36(2), 76-81. https://doi.org/10.1097/ 00006199-198703000-00002

Wang, D., Xing, X. H., \& Wu, X. B. (2013). Healthy lifestyles of university students in China and influential factors. The Scientific World Journal, 412950, 1-10. https://doi.org/10.1155/2013/412950

Wei, C. N., Harada, K., Ueda, K., Fukumoto, K., Minamoto, K., \& Ueda, A. (2012). Assessment of health-promoting lifestyle profile in Japanese university students. Environmental Health and Preventive Medicine, 17, 222-227. https://doi.org/10.1007/s12199-011-0244-8

World Health Organization. (2020). Health Emergency Dashboard. https://covid19.who.int/?gclid=EAIaI QobChMIy9GLsqiw6gIV19eyCh22iQ4gEAAYASAAEgK_hPD_BwE.

Wilcox, S., Der Ananian, C., Abbott, J., Vrazel, J., Ramsey, C., Sharpe, P. A., \& Brady, T. (2006). Perceived exercise barriers, enablers, and benefits among exercising and nonexercising adults with arthritis: Results from a qualitative study. Arthritis Care and Research, 55(4), 616-627. https://doi. org/10.1002/art.22098

Varela-Mato, V., Cancela, J. M., Ayan, C., Martín, V., \& Molina, A. (2012). Lifestyle and health among Spanish university students: Differences by gender and academic discipline. International Journal of Environmental Research and Public Health, 9(8), 2728-2741. https://doi.org/10.3390/ijerph9082 728

YalnızoğluÇaka, S., Topal, S., Karakaya Suzan, Ö., \& Çınar, N. (2017). Hemşirelik öğrencilerin sağlık algısı ile özgüvenleri arasındaki ilişki [The relationship between nursing students' health perception and self-confidence]. Journal of Human Rhythm, 3(4), 199-203.

Yan, Z., \& FitzPatrick, K. (2016). Acculturation and health behaviors among international students: A qualitative approach. Nursing and Health Sciences, 18(1), 58-63. https://doi.org/10.1111/nhs.12232

Publisher's Note Springer Nature remains neutral with regard to jurisdictional claims in published maps and institutional affiliations. 